\title{
Evaluation of the applicability of polymerase chain reaction (PCR) to sex identification in Eurasian blackbirds (Turdus merula)
}

\author{
ANDRZEJ DYBUS ${ }^{1}$, ANNA SIEMIERZ ${ }^{1}$, DARIUSZ WYSOCKI ${ }^{2}$, IWONA SZATKOWSKA ${ }^{1}$, \\ MAGDALENA MUSZYNSKA ${ }^{1}$ and SEBASTIAN GUENZEL ${ }^{3}$ \\ ${ }^{1}$ Laboratory of Molecular Cytogenetics, West Pomeranian University of Technology, Szczecin, \\ Doktora Judyma 10, 71-460 Szczecin, Poland, e-mail: Andrzej.Dybus@zut.edu.pl \\ ${ }^{2}$ Department of Anatomy and Vertebrate Zoology, University of Szczecin, Wąska, \\ 71-412 Szczecin, Poland \\ ${ }^{3}$ Department of Poultry and Ornamental Bird Breeding, West Pomeranian University of Technology, \\ Szczecin, Doktora Judyma 24, 71-466 Szczecin, Poland
}

(Received on 8 December 2008, Accepted on 22 April 2009)

\begin{abstract}
Turdus merula is one of most common bird species in Europe. This study verified a method for its sex identification by PCR with P2/P8 primers, based on the CHD1 gene polymorphism, proposed in earlier studies as a universal tool for sex identification in most bird species. Although there are some reports that PCR cannot determine sex in Eurasian blackbirds due to a lack of differences in intron lengths of $C H D 1-Z$ and $C H D 1-W$ genes, our study showed that such a possibility does exist, so it can contribute to an increased understanding of the biology of this species.
\end{abstract}

Keywords: CHD1, PCR, molecular sexing, blackbird, Turdus merula

\section{INTRODUCTION}

In most bird species, morphology-based sexing of chicks is impossible due to their weak sexual dimorphism. This considerably hinders some basic research, e.g. analyses of the adaptive adjustment of the primary sex ratio - one of the most important problems in evolutionary biology over recent years. It is also an obstacle in the threatened species re-introduction programs (Ewen et al. 2004; Cheng et al. 2006). Similar to mammals (Szat kowska et al. 2003), the process of sex determination and differentiation in birds is controlled by a complex molecular mechanism, which eventually leads to the development of gonads and reproductive tracts, consistent with the chromosomal sex. However, unlike mammals, bird females are heterogametic (ZW), while males are homogametic (ZZ). The functions of many autosomal genes involved in the process of sex determination in birds have been mapped and described (Sf1, Wt1, Sox9, Amh, Dax1), but the identification and role of genes linked 
to sex chromosomes in this complex process have not been determined in detail (ELLEGREN \& CARMICHAEL 2001).

A bird's sex can be identified in many ways, but in monomorphic species, or young individuals, molecular techniques may provide substantial support (SACHARCZUK et al. 2002). In the $\mathrm{W}$ chromosome there are several genes, but only the CHD1 gene (which encodes chromodomain-helicase-DNA-binding protein 1) has been applied to sex identification. This is due to the fact that the CHD1 gene, mapped in the $\mathrm{W}$ chromosome (W-linked), has a homologous copy also in the $\mathrm{Z}$ chromosome (Z-linked) (GRIFFITHS \& KORN 1997). Although both variants are extremely conservative (GRIFFITHS \& KoRn 1997; EllEGREN \& CARMiCHAEL 2001), they can still differ with regard to the length of their intron sequences (depending on species), enabling differentiation between the copies from the $\mathrm{W} / \mathrm{Z}$ chromosomes. A test using the extremely conservative gene $C H D$ can be a universal tool of sex identification for almost all bird classes, except for the ratites, in which the intron lengths of the CHD-W and CHD-Z genes are identical (ELLEGREN 1996; GRIFFITHS et al. 1998).

Turdus merula is one of most common bird species in Europe. Its range covers most of Europe (except its northern and northeastern fringes), North Africa, and Central Asia as far as China. Populations introduced by man also occur in Australia and New Zealand (CRAMP \& Simmons 1988). Originally, the species was connected with broadleaf and mixed forests, but since the mid-19th century it began to colonize the cities of Western Europe. At present, this process progresses towards the north-east (Mulsow \& Tomialojć 1997). Numbers in the examined populations in most areas are stable (NEwTON 2004). Due to the presence of high-density urban populations, the distinct sexual dimorphism of adult individuals (brown female and black male), and the nests built at relatively small heights (CRAMP \& SimMOns 1988), the Eurasian blackbird is the most often examined bird species building open nests in Europe, so it often serves as a model for other species (MAGRATH 1989; MAGRATH 1991; WYSOCKI 2004; Wysocki 2006). Although in adult individuals sex can be identified based on plumage colour, alternative methods are necessary in chicks, and all the more in dead embryos.

Criteria used in choosing alternative methods of sex identification should take into account several significant issues, but first of all, the method should be as noninvasive as possible. Diagnostic tests based on DNA analysis are exactly that, because DNA can be obtained from a single feather or a drop of blood (ITO et al. 2003). Moreover, once obtained, blood or tissue samples, regardless of the age of the examined birds, can be kept for long periods of time and used many times in later analyses (EASON et al. 2001). It is also possible to isolate DNA from feathers cast down during moulting, which makes it easy to identify the sex of very rare, threatened, or the last free-living birds of a species.

The aim of this study was to evaluate the applicability of PCR in sex determination of Eurasian blackbirds (Turdus merula), on the basis of the polymorphism of the CHD1 gene and using the primer sequences proposed previously for sex identification in other bird species. 


\section{MATERIALS AND METHODS}

The research involved 99 blackbird nestlings, living in city parks in Szczecin (NW Poland). DNA was isolated from quills (BELlo et al. 2001). The sex of the birds was identified using PCR with the P2/P8 primers (GRIFFITHs et al. 1998). The PCR mixture contained a buffer for Taq polymerase $(50 \mathrm{mM} \mathrm{KCl}, 10 \mathrm{mM}$ Tris- $\mathrm{HCl}, 0.01 \%$ Triton $\left.{ }^{\mathrm{TM} X}-100,1.5 \mathrm{mM} \mathrm{MgCl} 2\right), 0.2 \mathrm{mM}$ dNTP, 10 pmol of each primer, 0.4 units of Taq-polymerase (MBI Fermentas), 50 ng of genomic DNA, and up to $15 \mu$ l of deionized water. The PCR was carried out in T-personal (Biometra) and GeneAmp PCR System 2400 (Perkin Elmer) thermocyclers under the following thermal conditions: initial denaturation of DNA at $94^{\circ} \mathrm{C}$ for $5 \mathrm{~min}$, and in the subsequent 33 cycles at $94^{\circ} \mathrm{C}$ for $1 \mathrm{~min}$, annealing of primers at $54^{\circ} \mathrm{C}$ for $1 \mathrm{~min}$, DNA synthesis at $72^{\circ} \mathrm{C}$ for $1 \mathrm{~min}$, and the final elongation cycle at $72^{\circ} \mathrm{C}$ for $5 \mathrm{~min}$. The applied temperature for primer annealing was higher than in the original method in order to eliminate unspecific products. Amplification products were separated by horizontal electrophoresis $(90 \mathrm{~V}, 50 \mathrm{~min})$ in $3 \%$ agarose gels (PRONA) in $1 \times \mathrm{TBE}$ and $0.5 \mu \mathrm{M}$ ethidium bromide. The results of electrophoresis were read under UV light (312 nm).

To determine the DNA sequences of $C H D 1-Z$ and $C H D 1-W$, specific amplicons (bands) were isolated from agarose gels by using DNA Gel-Out (A\&A Biotechnology), sequenced in an ABI Prism Sequencer (Perkin-Elmer), and analyzed using Chromas 2.31 software. The sequencing was done at the Institute of Biochemistry and Biophysics, Polish Academy of Sciences, Warsaw, Poland. The obtained results were analyzed using BLAST software (ZHANG et al. 2000).

\section{RESULTS}

The applied P2/P8 primers, according to GRIFFITHS et al. (1998), enabled an effective and specific amplification of a selected region of the CHD1-W gene and its homologous copy CHD1-Z. PCR products were 394/349 bp in length (CHD1-W/ CHD1-Z). In order to confirm the amplification specificity and identify differences in the lengths of introns in the 2 genes, we sequenced the obtained PCR products. Our results were compared with GenBank data (BLAST). Analysis of the amplified exon sequences (152 bp) confirmed that the sequences of PCR products obtained in this study (deposited in GenBank, DQ517890 and DQ517891) were fragments of the $C H D 1-Z$ and $C H D 1-W$ genes. Moreover, the homology was determined with analogous exon sequences of other bird species (Table 1).

The polymorphic variants of the CHD1-W and CHD1-Z genes obtained in this study resulted from the variable length of the amplified introns. These sequences were compared and deletion sites were presented in the sequence of CHD1-Z (Figure 1), which was shorter than that of $C D H 1-W$ by about $45 \mathrm{bp}$. Accordingly, the electrophoretic image revealed a single amplicon in the homogametic males (ZZ), and 2 amplicons in females (ZW) (Figure 2).

In the examined population of 99 ringed blackbird nestlings, we molecularly identified 58 females and 41 males, and the results were verified in the following breeding season, on the basis of the plumage colouration of adult individuals already 
Table 1. Comparison of CHD1 exon sequences of Turdus merula with those of other species, based on GenBank accessions

\begin{tabular}{clcc}
\hline $\begin{array}{c}\text { Accession number of } \\
\text { Turdus merula CHD1 }\end{array}$ & Species & $\begin{array}{c}\text { Accession number } \\
\text { of its CHD1 }\end{array}$ & $\begin{array}{c}\text { Identity } \\
\text { (\%) }\end{array}$ \\
\hline CHD1-Z, DQ517891 & $\begin{array}{l}\text { Taeniopygia guttata } \\
\text { (zebra finch) } \\
\text { Parus caeruleus } \\
\text { (blue tit) }\end{array}$ & AF006661 & 98 \\
\hline
\end{tabular}

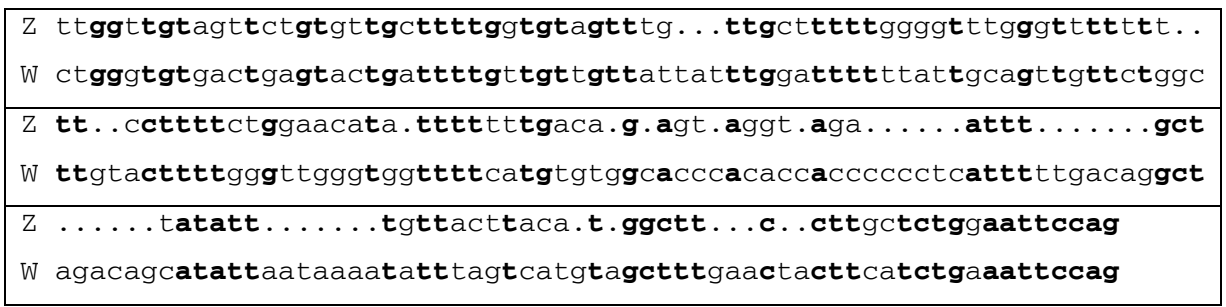

Fig. 1. Comparison of intron sequences of Turdus merula CHD1-Z and CHD1-W genes (DQ517891, DQ517890). Identical nucleotides are printed in bold; deletion sites (i.e. absence in CHD1-W) are marked with dots

having a distinct sexual dimorphism. There was $100 \%$ consistency between the molecular analyses and the later observation of plumage.

\section{DISCUSSION}

When the $\mathrm{W}$ chromosome was found to be characteristic only for females of birds, it became an interesting model not only in the search for specific genes involved in the process of sex determination in birds, but also in the identification of a possible variance that could differentiate between the heterochromosomes W and Z (NESJE \& Ř̌ED 2000). The first primers (P2 and P3), proposed by GRIFFITHS $\&$ TiWARI (1995), amplified the exon of both copies of the CHD1 gene, and the obtained PCR products differed only slightly with regard to the length of the sequence, which ranged from 60 to $110 \mathrm{bp}$, depending on species (Ellegren \& SHELdON 1997). Consequently, Griffiths et al. (1998) proposed to use P2/P8 primers, enabling the amplification of short coding sections of both gene copies (CHD1-W and CDH1-Z) and an intervening intron, variable with respect to its sequence and length. Thanks to the fact that this gene appears in both heterochromosomes, the PCR product will be ever-present, which excludes false negative results. 


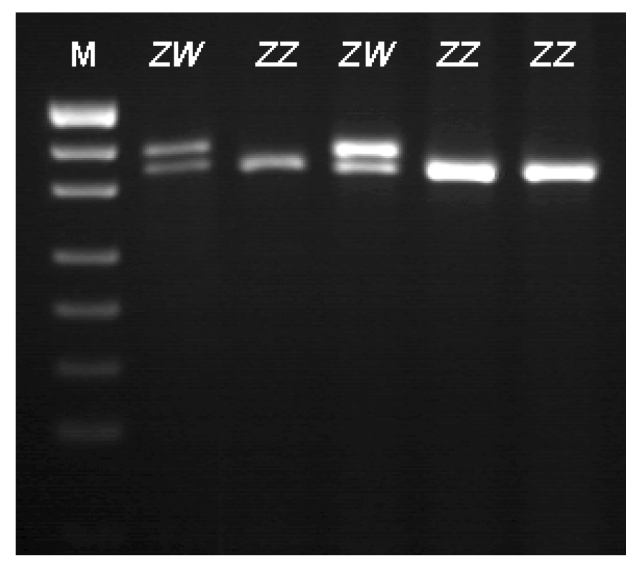

Fig. 2. Representative results of PCR analysis. $M=$ pUC19/MspI (MBI Fermentas)

Differences in the lengths of amplicons, specific for the CHD1-Z and CHD1-W genes, resulted in this study from different lengths of the intron sequence, but the precise determination of the entire intron length in the CHDI- $W$ gene, based on sequencing results using $\mathrm{P} 2 / \mathrm{P} 8$, proved to be difficult. Nonetheless, given the migration rate of the longer amplicon in agarose gel, the length of the homologous intron sequence of the CHD1-W gene in Hemispingus frontalis (206 bp) and Taeniopygia guttata (208 $\mathrm{bp}$ ), and the fact that the analogous intron of the CHD1-Z copy was $168 \mathrm{bp}$ long, with deletions of $45 \mathrm{bp}$, it can be supposed that the full intron sequence of the gene CHD1-W in Eurasian blackbirds should have a length of $213 \mathrm{bp}$.

FRIDOLFSSON \& ELLEGREN (1999) proposed another pair of primers useful in sexing protocols (2550F/2718R). In Eurasian blackbirds, however, the 2550F/2718R primers amplified a single identical product in both sexes (DAwson et al. 2001). The PCR technique using P2/P8 primers appears to be a better method of sex identification in passerines. Our study shows that it is useful for sex identification in blackbirds, so it can contribute to an increased understanding of biology of this species.

\section{REFERENCES}

Bello N., Francino O., Sanchez A. 2001. Isolation of genomic DNA from feathers. J. Vet. Diagn. Invest. 13: 162-164.

Cheng Y-H., Kuo T-F., Lee D-N., Weng C-F. 2006. Sex Identification of the Black-faced Spoonbill (Platalea minor). Zool. Stud. 45: 104-113.

Chromas, v. 2.31. http://www.technelysium.com.au/chromas.html

Cramp S., Simmons K.E.K. (eds). 1988. The birds of the Western Palearctic. Oxford Univ. Press.

Dawson D.A., Darby S., Hunter F.M., Krupa A.P., Jones I.L., Burke T. 2001. A critique of avian CHD-based molecular sexing protocols illustrated by a Z-chromosome polymorphism detected in auklets. Mol. Ecol. Notes. 1: 201-204. 
Eason D., Millar C.D., Cree A., Halverson J., Lambert D.M. 2001. A comparison of five methods for assignment of sex in the takahe (Aves: Porphyrio mantelli). J. Zool. 253: 281-292.

Ellegren H. 1996. First gene on the avian W chromosome (CHD) provides a tag for universal sexing of non-ratite birds. Proc. Biol. Sci. 263: 1635-1644.

Ellegren H., Carmichael A. 2001. Multiple and independent cessation of recombination between avian sex chromosomes. Genetics. 158: 325-331.

Ellegren H., Sheldon B.C. 1997. New tools for sex identification and the study of sex allocation in birds. Trends Ecol. Evol. (Amst.). 12: 255-259.

Ewen G.E., CASSEy P., MŘLler A.P. 2004. Facultative primary sex ratio variation: a lack of evidence in birds? Proc. Biol. Sci. 171: 1277-1283.

Fridolfsson A.K., Ellegren H. 1999. A simple and universal method for molecular sexing of nonratite birds. J. Avian Biol. 30: 116-121.

Griffiths R., Double M., Orr K., Dawson R. 1998. A DNA test to sex most birds. Mol. Ecol. 7: $1071-1075$.

Griffiths R., Korn R. 1997. A CHD1 gene is Z chromosome linked in the chicken Gallus domesticus. Gene. 197: 225-229.

Griffiths R., Tiwari B. 1995. Sex of the last wild Spix's macaw. Nature. 375: 454.

Ito H., Sudo-Yamaл A., Aвe M., Murase T., Tsubota T. 2003. Sex identification by alternative polymerase chain reaction methods in falconiformes. Zool. Sci. 20: 339-344.

Magrath R.D. 1989. Hatching asynchrony and reproductive success in the Blackbird. Nature. 339: $536-538$.

Magrath R.D. 1991. Nestling weight and juvenile survival in the Blackbird, Turdus merula. J. Anim. Ecol. 60: 335-351.

Mulsow R., Tomialojć L. 1997. Blackbird. In: The EBCC Atlas of European Breeding Birds: Their Distribution and Abundance (Hagemeijer WJM, Blair MJ, eds.), T \& A D Poyser, London. 544-545.

NESJE M., RŘED K.H. 2000. Sex identification in falcons using microsatellite DNA markers. Hereditas. 132: 261-263.

NEwTON I. 2004. The recent declines of farmland bird populations in Britain: an appraisal of causal factors and conservation actions. Ibis. 146: 579-600.

SacharczuK M., Jaszczak K., Kruszewicz A. 2002. Sex identification in monomorphic birds a review. Pr. Mater. Zoot. 60: 35-50.

SZATKOWSKa I., ZyCh S., Kulig H. 2003. Sex determination in mammals. Med. Weter. 59, 847-852.

Wysocki D. 2004. Within-season divorce rate in an urban population of European Blackbird Turdus merula. Ardea. 92: 219-228.

Wysocki D. 2006. Factors affecting the between-season divorce rate in the urban population of European Blackbird Turdus merula in north-western Poland. Acta Ornithol. 41: 71-78.

Zhang Z., Schwartz S., Wagner L., Miller W. 2000. A greedy algorithm for aligning DNA sequences. J. Comput. Biol. 7:203-14. 